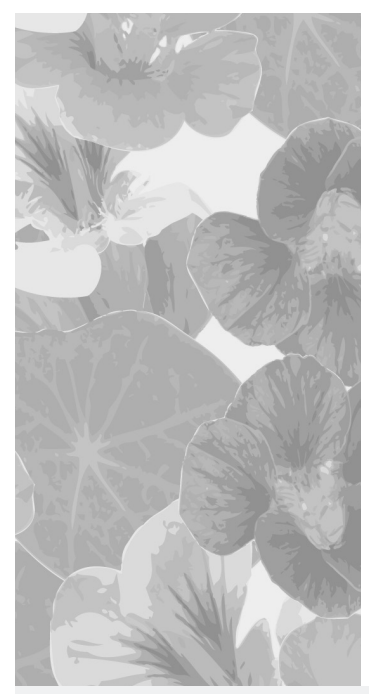

\title{
Badania motywów wyboru rodzajów mikrodermabrazji oraz opinii o ich skuteczności w praktyce kosmetologicznej
}

\section{A survey of the motives for selecting the types of microdermabrasion and the opinion on their effectiveness in cosmetology practice}

Katarzyna Kordus, Barbara Potempa, Radosław Śpiewak

Zakład Dermatologii Doświadczalnej i Kosmetologii, Wydział Farmaceutyczny Uniwersytet Jagielloński Collegium Medicum, Kraków

Estetol Med Kosmetol 2011; 1(1): 21-26

DOI : http://dx.doi.org/10.14320/EMK.2011.004

\section{Streszczenie}

Mikrodermabrazja jest jednym z najczęściej wykonywanych zabiegów złuszczania naskórka w gabinetach kosmetologicznych. Aktualnie stosowane są trzy odmiany mikrodermabrazji: diamentowa, korundowa oraz wodno-tlenowa (oksybrazja). Różnią się między sobą rodzajem środka ściernego, zasadą wykonywania zabiegu i intensywnością. Dotychczas nie badano motywów, jakimi kierują się polscy kosmetolodzy podejmując decyzje o wyborze rodzaju mikrodermabrazji do swojego gabinetu. Cel: Zbadanie częstości stosowania poszczególnych rodzajów mikrodermabrazji przez kosmetologów, a także ich opinii na temat postrzeganych różnic w działaniu, skuteczności i bezpieczeństwa, które wpływają na ich preferencje przy wyborze techniki zabiegu. Materiat i metody: Przeprowadzono badania ankietowe 100 polskich kosmetologów wykonujących co najmniej jeden rodzaj mikrodermabrazji. Wyniki: Zabiegiem złuszczania naskórka najczęściej wykonywanym przez badanych kosmetologów była mikrodermabrazja diamentowa - spośród 100 respondentów wykonywały ją 94 osoby (94\%). Wykonywanie mikrodermabrazji wodno-tlenowej zadeklarowato 17\% respondentów, natomiast mikrodermabrazji korundowej 15\%. Z innych stosowanych metod złuszczania naskórka, ankietowani wymieniali peeling kawitacyjny (92\%), peelingi chemiczne (78\%), oraz peelingi ziołowe (21\%). Spośród odmian mikrodermabrazji, ankietowani kosmetolodzy najwyżej oceniają skuteczność mikrodermabrazji korundowej, w dalszej kolejności mikrodermabrazji diamentowej, natomiast mikrodermabrazja wodnotlenowa oceniana jest jako najmniej skuteczna. Głównymi motywami wyboru mikrodermabrazji diamentowej przez kosmetologów były duży popyt ze strony klientów, prostota wykonywania i opłacalność zabiegu, mikrodermabrazji wodno-tlenowej-higieniczność, bezpieczeństwo i prostota wykonania, zaś mikrodermabrazji korundowej - higieniczność, skuteczność i atrakcyjność dla klientów. Wnioski: Najczęściej wybieranym przez polskich kosmetologów zabiegiem ztuszczania naskórka jest mikrodermabrazja diamentowa. Kosmetolodzy najrzadziej sięgają po mikrodermabrazję korundową, mimo że jest ona postrzegana przez użytkowników jako najbardziej efektywna odmiana mikrodermabrazji.

Stowa kluczowe: mikrodermabrazja diamentowa, mikrodermabrazja korundowa, mikrodermabrazja wodno-tlenowa, oksybrazja, kryteria wyboru, preferencje, skuteczność, bezpieczeństwo

\begin{abstract}
Microdermabrasion is one of the most popular methods of skin exfoliation in beauty salons. At present, three variants of microdermabrasion are used: diamond, corundum and hydradermabrasion. They differ in the type of abrasive material, principle of application, and intensity. The motives driving Polish cosmetologists at choosing a particular type of microdermabrasion for their practice had not yet been studied. Aim: To study the frequency of using particular types of microdermabrasion among cosmetologists, and their opinions regarding the differences in mode of action, effectiveness and safety of particular techniques that may determine their choice. Material and methods: A questionnaire survey of 100 Polish cosmetologists who perform at least one type of microdermabrasion. Results: The most frequently used method of exfoliation was the diamond microdermabrasion, as indicated by 94 out of 100 respondents (94\%). Using hydrodermabrasion was admitted by $17 \%$ respondents, and corundum microdermabrasion by $15 \%$. Among other techniques of skin exfoliation, cavitation ( $92 \%$ ), chemical peeling (78\%), and herbal peeling (21\%) were used by the respondents. Of the microdermabrasion techniques, study participants rated corundum microdermabrasion as most effective, followed by diamond microdermabrasion, while hydradermabrasion was considered least effective. Major motives for selecting diamond microdermabrasion for their practice as indicated by the cosmetologists were: big demand of customers ease of application and profitability, for hydradermabrasion - sanitary advantages, safety and ease of application, while for corundum microdermabrasion - sanitary advantages, effectiveness and attractiveness to the customers. Conclusions: The technique of skin exfoliation most frequently used by Polish cosmetologists is diamond microdermabrasion. Corundum microdermabrasion is the least popular technique in spite of its highest effectiveness as perceived by the users.
\end{abstract}

Key words: diamond microdermabrasion, corundum microdermabrasion, hydradermabrasion, preferences, criteria of choice, effectiveness, safety

Copyright @ 2011 the Authors (text) and Radosław Śpiewak (layout \& journal compilation). All rights reserved. 
Mikrodermabrazja to zabieg kosmetyczny polegający na mechanicznym ścieraniu warstwy rogowej naskórka. Technika ta pozwala na wzrokową kontrolę głębokości złuszczania w trakcie zabiegu. Stopień głębokości mikrodermabrazji zależy od wartości stosowanego podciśnienia, czasu oddziaływania, wielkości ziaren materiału ściernego, a w przypadku mikrodermabrazji wodno-tlenowej od odległości dyszy od skóry [1,2]. Mikrodermabrazja wykorzystywana jest ponadto do zwiększania przezskórnej penetracji substancji aktywnych, gdyż ścierając warstwę rogową redukuje się efektywność bariery naskórkowej [3].

Różnice między mikrodermabrazją a dermabrazją. Dermabrazja jest wykonywanym przez lekarzy zabiegiem głębokiego złuszczania, wymagającym znieczulenia ogólnego lub miejscowego. Podczas dermabrazji złuszczany jest cały naskórek i górne warstwy skóry właściwej. Efektem zabiegu jest przebudowa struktury skóry. Ze względu na długi czas gojenia zabieg dermabrazji wymaga zwykle wzięcia urlopu przez pacjentkę. Mikrodermabrazja to zabieg powierzchowny, w trakcie którego złuszcza się jedynie zewnętrzne warstwy naskórka, co zasadniczo odpowiada przyspieszeniu naturalnego procesu złuszczania [4-7]. Zaletą mikrodermabrazji jest to, że klientka po zabiegu może natychmiast powrócić do czynności życiowych. W związku z małą inwazyjnością, po zabiegu mikrodermabrazji rzadko występują powikłania, jednak aby uzyskać widoczną poprawę stanu skóry konieczne jest wielokrotne powtarzanie aplikacji. Mikrodermabrazja może być wykonywana zarówno przez lekarzy, jak i przez kosmetologów.

Rodzaje mikrodermabrazji. Rozróżnia się trzy rodzaje mikrodermabrazji: diamentową, korundową oraz wodno-tlenową. Mikrodermabrazja diamentowa polega na ścieraniu mechanicznym zrogowaciałej warstwy naskórka przy pomocy głowic diamentowych, które mogą różnić się między sobą średnicą i średnicą ziaren diamentu. Wybór średnicy i ziarnistości determinuje rozległość zabiegu i głębokość złuszczania naskórka. W trakcie zabiegu wykonujący ściera skórę przesuwając głowicę w ustalonym kierunku i powtarzając procedurę do osiągnięcia zamierzonego efektu. W mikrodermobrazji korundowej do złuszczania zrogowaciałego naskórka wykorzystuje się zmikronizowane kryształy korundu (odmiana tlenku glinu), które wyrzucane pod ciśnieniem z dyszy dają efekt ,piaskowania”. Druga dysza zasysa zużyty korund i złuszczony naskórek [8-9]. Podczas zabiegu dochodzi do znacznego pylenia, W związku z czym kosmetolog powinien wykonywać zabieg w masce, a klienta należy zaopatrzyć w okulary ochronne. Korund nie wchłania się przez skórę. Jego właściwości bakteriobójcze sprawiają, że jest polecany w trądziku pospolitym [10]. Mikrodermabrazja wodno-tlenowa, czyli oksydermabrazja to aplikacja strumienia roztworu soli fizjologicznej $(0,9 \% \mathrm{NaCl})$ i sprężonego powietrza [2,11]. Dysza oddalona jest od skóry o 0,5-1 cm. Strumień wodno-tlenowy wyrzucany z dyszy z prędkością $200 \mathrm{~m} / \mathrm{s}$ złuszcza powierzchowne warstwy naskórka. Jest to metoda o minimalnym ryzyku powikłań gdyż używane są substancje obojętne dla skóry, a cały zabieg odbywa się bez kontaktu dyszy ze skórą. Rozprężanie strumienia powoduje schłodzenie tkanek, co ogranicza dyskomfort podczas złuszczania i minimalizuje ryzyko krwawienia czy wysięku. Aby zabieg był skuteczny i bezpieczny, niezbędna jest wiedza na temat wskazań i przeciwwskazań do wykonywania danego rodzaju mikrodermabrazji. Tabela 1 przedstawia zestawienie wskazań, a tabela 2 wykaz przeciwwskazań do zabiegów mikrodermabrazji na podstawie dostępnej literatury.

Tabela 1. Wskazania do zabiegu mikrodermabrazji [12-14]

\begin{tabular}{|c|c|c|c|}
\hline Wskazanie & $\begin{array}{l}\text { Mikrodermabrazja } \\
\text { korundowa }\end{array}$ & $\begin{array}{l}\text { Mikrodermabrazja } \\
\text { diamentowa }\end{array}$ & $\begin{array}{c}\text { Mikrodermabrazja } \\
\text { wodno-tlenowa }\end{array}$ \\
\hline Szorstkość skóry & + & + & + \\
\hline Matowość skóry & + & + & + \\
\hline $\begin{array}{l}\text { Poszerzone uj- } \\
\text { ścia gruczołów ło- } \\
\text { jowych }\end{array}$ & + & + & + \\
\hline $\begin{array}{l}\text { Zaskórniki otwarte } \\
\text { i zamknięte }\end{array}$ & + & + & + \\
\hline Prosaki & + & + & + \\
\hline Hiperpigmentacja & + & + & + \\
\hline Ostudy & + & + & + \\
\hline Plamy starcze & + & + & + \\
\hline Fotostarzenie skóry & + & + & + \\
\hline $\begin{array}{l}\text { Posłoneczne defek- } \\
\text { ty skórne }\end{array}$ & + & + & + \\
\hline $\begin{array}{l}\text { Rogowacenie łojo- } \\
\text { tokowe }\end{array}$ & - & + & + \\
\hline $\begin{array}{l}\text { Rogowacenie } \\
\text { mieszkowe }\end{array}$ & + & + & + \\
\hline $\begin{array}{l}\text { Powierzchowne } \\
\text { zmarszczki }\end{array}$ & + & + & - \\
\hline $\begin{array}{l}\text { Trądzik grudko- } \\
\text { wo-krostkowy }\end{array}$ & - & - & + \\
\hline $\begin{array}{l}\text { Blizny potrądzi- } \\
\text { kowe }\end{array}$ & + & + & - \\
\hline Trądzik różowaty & - & - & + \\
\hline Teleangiektazje & - & - & + \\
\hline $\begin{array}{l}\text { Powierzchowne } \\
\text { blizny }\end{array}$ & + & + & + \\
\hline Rozstępy & + & + & + \\
\hline Tatuaż & + & + & - \\
\hline $\begin{array}{l}\text { Zwiększenie pene- } \\
\text { tracji składników } \\
\text { aktywnych }\end{array}$ & + & + & + \\
\hline $\begin{array}{l}\text { Skóra thusta } \\
\text { i mieszana }\end{array}$ & + & + & + \\
\hline Skóra odwodniona & + & + & + \\
\hline
\end{tabular}


Tabela 2. Przeciwwskazania do zabiegu mikrodermabrazji $[12,14]$

\begin{tabular}{|c|c|c|c|}
\hline Przeciwwskazanie & $\begin{array}{l}\text { Mikrodermabrazja } \\
\text { korundowa }\end{array}$ & $\begin{array}{l}\text { Mikrodermabrazja } \\
\text { diamentowa }\end{array}$ & $\begin{array}{l}\text { Mikrodermabrazja } \\
\text { wodno-tlenowa }\end{array}$ \\
\hline Ciąża & + & + & - \\
\hline Czerniak & + & + & + \\
\hline $\begin{array}{l}\text { Podejrzane zmiany } \\
\text { skórne }\end{array}$ & + & + & + \\
\hline $\begin{array}{l}\text { Leczenie izotretinoiną } \\
\text { (do } 12 \text { miesięcy od } \\
\text { zakończenia kuracji) }\end{array}$ & + & + & + \\
\hline $\begin{array}{l}\text { Choroby } \\
\text { autoimunologiczne }\end{array}$ & + & + & + \\
\hline Terapia antykoagulacyjna & + & + & + \\
\hline $\begin{array}{l}\text { Zabiegi chirurgiczne do } 2 \\
\text { miesięcy przed zabiegiem }\end{array}$ & + & + & + \\
\hline $\begin{array}{l}\text { Tendencja } \\
\text { do bliznowacenia }\end{array}$ & + & + & + \\
\hline $\begin{array}{l}\text { Aktywna infekcja } \\
\text { w miejscu zabiegu }\end{array}$ & + & + & + \\
\hline Oparzenia słoneczne & + & + & + \\
\hline $\begin{array}{l}\text { Trądzik krostkowo- } \\
\text { cystowy }\end{array}$ & + & + & + \\
\hline $\begin{array}{l}\text { Traadzik grudkowo- } \\
\text { krostkowy }\end{array}$ & + & + & - \\
\hline Trądzik różowaty & + & + & - \\
\hline Teleangiektazje & + & + & - \\
\hline Rumień & + & + & - \\
\hline Skóra cienka i wrażliwa & + & + & - \\
\hline $\begin{array}{l}\text { Przewlekłe lub } \\
\text { nawrotowe zapalenie } \\
\text { zatok (gdy zabieg } \\
\text { wykonywany jest } \\
\text { na twarzy) }\end{array}$ & - & - & + \\
\hline $\begin{array}{l}\text { Nierealistyczne } \\
\text { oczekiwania pacjenta }\end{array}$ & + & - & - \\
\hline
\end{tabular}

\section{Cel pracy}

Celem badania było poznanie częstości stosowania przez polskich kosmetologów trzech odmian mikrodermabrazji: diamentowej, korundowej, wodnotlenowej, a ponadto ich opinii na temat poszczególnych odmian mikrodermabrazji: ich skuteczności, postrzeganych wad i zalet tych metod, a także motywów wyboru danego zabiegu do swojego gabinetu.

\section{Materiat i metody}

Przeprowadzono badania ankietowe 100 kosmetologów z całej Polski wykonujących co najmniej jeden rodzaj mikrodermabrazji. Badania główne zostały poprzedzone ankietą pilotażową, składającą się z pytań otwartych na temat opinii o poszczególnych odmianach mikrodermabrazji. Po przeanalizowaniu odpowiedzi i wyłonieniu typowych, najczęściej powtarzających się opinii stworzono ankietę właściwą z pytaniami zamkniętymi jedno- i wielokrotnego wyboru, która podzielona była na część ogólną i części szczegółowe poświęcone poszczególnym odmianom mikrodermabrazji. W ankiecie głównej pytano o to, jaki rodzaj zabiegu i jak często wykonuje ankietowany, a w przypadku niewykonywania danego rodzaju mikrodermabrazji proszono o podanie przyczyn. Części szczegółowe ankiety poświęcone były każda jednej $\mathrm{z}$ trzech odmian mikrodermabrazji i były wypełniane tylko przez tych respondentów, którzy wykonywali dany zabieg. W części szczegółowej pytano o motywy wyboru danego rodzaju mikrodermabrazji, opinie na temat skuteczności metody oraz obserwowane powikłania. Ankieta zawierała również pytanie o to, kto w opinii ankietowanych - kosmetolog czy lekarz - posiada odpowiednie kwalifikacje do wykonywania poszczególnych typów mikrodermabrazji.

\section{Wyniki}

Zabiegiem złuszczania naskórka najczęściej wykonywanym przez badanych kosmetologów okazała się mikrodermabrazja diamentowa. Spośród 100 respondentów wykonywały ją 94 osoby (94\%) - 43\% respondentów podało, że stosuje tę metodę powyżej 20 razy w miesiącu (przeciętnie co najmniej raz dziennie), a 51\% wykonywało ją rzadziej. $Z$ innych stosowanych metod złuszczania naskórka, ankietowani wymieniali peeling kawitacyjny (92\%), peelingi chemiczne (78\%), oraz peelingi ziołowe (21\%).

Mikrodermabrazja diamentowa. Motywy, jakimi kierowali się ankietowani wybierając ten zabieg przedstawia ryc. 1. Mikrodermabrazję diamentową respondenci ocenili jako skuteczną w usuwaniu przebarwień i drobnych zmarszczek, obkurczaniu porów, zmniejszaniu łojotoku i szorstkości skóry oraz likwidacji rogowacenia okołomieszkowego (tab. 3). 69\% respondentów wykonujących ten zabieg uznało intensywność mikrodermabrazji diamentowej za wystarczającą dla ich potrzeb, natomiast 31\% kosmetologów uznała, że metoda nie jest dostatecznie intensywna. Powikłania pozabiegowe w postaci rumienia i zwiększonej wrażliwości skóry respondenci obserwowali rzadko (61\%) lub nigdy (39\%). Wszyscy respondenci wyrazili opinię, że kosmetolog posiada kwalifikacje do wykonywania tego zabiegu. $6 \%$ respondentów nie wykonuje mikrodermabrazji diamentowej, a ich motywy przedstawia ryc. 2.

Rycina 1. Motywy wyboru mikrodermabrazji diamentowej przez stosujących ją kosmetologów ( $\mathrm{N}=94)$

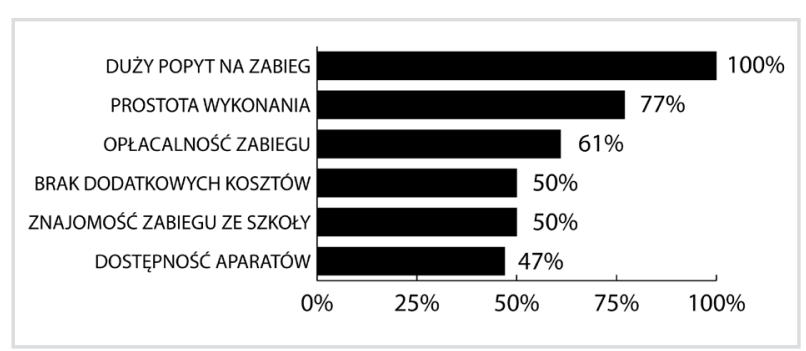


Tabela 3. Skuteczność zabiegu mikrodermabrazji diamentowej w opinii kosmetologów stosujących tę metodę ( $N=94)$

$\begin{array}{llll}\text { Wskazanie } & \begin{array}{l}\text { Zabieg } \\ \text { skutecrny }\end{array} & \begin{array}{l}\text { Zabieg raczej } \\ \text { skuteczny }\end{array} & \begin{array}{l}\text { Zabieg } \\ \text { nieskuteczny }\end{array} \\ \text { Zmniejszanie szorstkości skóry } & 70(75 \%) & 20(21 \%) & 4(4 \%) \\ \text { Usuwanie przebarwień } & 35(37 \%) & 54(58 \%) & 5(5 \%) \\ \text { Obkurczanie porów } & 35(37 \%) & 46(49 \%) & 23(24 \%) \\ \text { Zmniejszanie łojotoku } & 29(31 \%) & 42(45 \%) & 23(24 \%) \\ \text { Likwidacja rogowacenia okołomieszkowego } & 28(30 \%) & 57(60 \%) & 10(10 \%) \\ \text { Likwidacja drobnych zmarszczek } & 19(20 \%) & 69(74 \%) & 6(6 \%) \\ \text { Zwiększenie gęstości skóry } & 15(15 \%) & 47(51 \%) & 31(34 \%)\end{array}$

Rycina 2. Powody niewykonywania mikrodermabrazji diamentowej podane przez kosmetologów, którzy tej metody nie stosowali $(\mathrm{N}=6)$

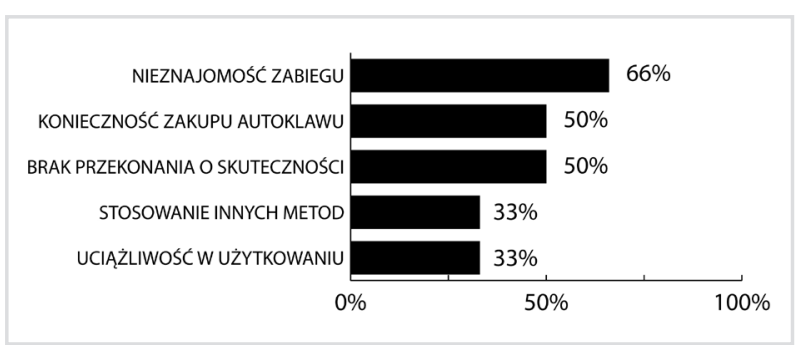

Mikrodermabrazja wodno-tlenowa. Metoda ta została przez ankietowanych oceniona jako najmniej skuteczna, jednak nie jest najrzadziej wybieranym zabiegiem - jej stosowanie w swojej praktyce zadeklarowało 17 (17\%) respondentów. Postrzegane przez respondentów cechy mikrodermabrazji wodno-tlenowej przemawiające za jej wyborem przedstawia rycina 3. Jedynie 4 z 17 respondentów stosujących tę metodę wyraziło satysfakcję z jej intensywności, zaś w opinii 10 respondentów zabieg ten był niedostatecznie intensywny. Tabela 4 przedstawia opinie na temat skuteczności mikrodermabrazji wodno-tlenowej z punktu widzenia stosujących ją kosmetologów, natomiast rycina 4 podsumowuje motywy jej niestosowania podane przez pozostałych respondentów.

Rycina 3. Motywy wyboru mikrodermabrazji wodno-tlenowej przez stosujących ją kosmetologów ( $\mathrm{N}=17)$

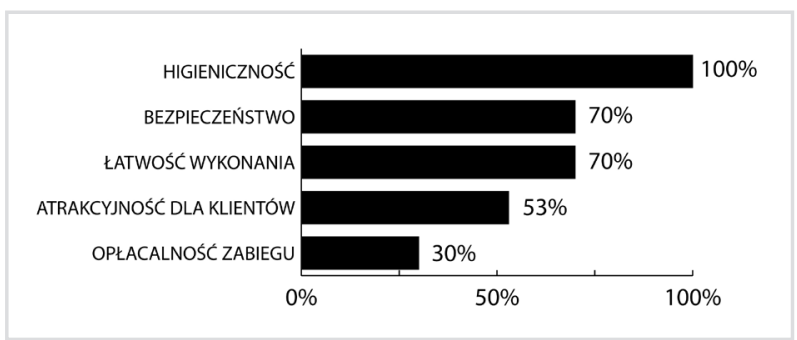

Mikrodermabrazja korundowa okazała się najrzadziej stosowaną odmianą mikrodermabrazji - tylko 15 spośród 100 respondentów (15\%) potwierdziło fakt jej wykonywania. Motywy wyboru mikrodermabra- zji korundowej w tej grupie przedstawia rycina 5, zaś tabela 5 podsumowuje opinie użytkowników na temat skuteczności tej metody. Wszyscy użytkownicy wyrazili pełną satysfakcję z intensywności zabiegu, jednak $53 \%$ obserwowało czasami powikłania pozabiegowe w postaci rumienia i zwiększonej wrażliwości skóry, a 7\% obserwowało takie powikłania dość często.

Tabela 4. Skuteczność mikrodermabrazji wodno-tlenowej w opinii kosmetologów stosujących tę metodę $(\mathrm{N}=17)$

$\begin{array}{llll}\text { Wskazanie } & \begin{array}{l}\text { Zabieg } \\ \text { skutecrny }\end{array} & \begin{array}{l}\text { Zabieg } \\ \text { raczej } \\ \text { skutecrny }\end{array} & \begin{array}{l}\text { Zabieg } \\ \text { nieskutecrny }\end{array} \\ \text { Zmniejszanie szorstkości skóry } & 5(30 \%) & 6(35 \%) & 6(35 \%) \\ \text { Likwidacja rogowacenia okołomieszkowego } & 1(6 \%) & 6(35 \%) & 10(59 \%) \\ \text { Zwiększenie gęstości skóry } & 1(6 \%) & 4(24 \%) & 12(70 \%) \\ \text { Obkurczanie porów } & 1(6 \%) & 3(17 \%) & 13(77 \%) \\ \text { Likwidacja drobnych zmarszczek } & 0 & 7(41 \%) & 10(59 \%) \\ \text { Zmniejszanie łojotoku } & 0 & 5(30 \%) & 12(70 \%) \\ \text { Usuwanie przebarwień } & 0 & 1(6 \%) & 16(94 \%)\end{array}$

Rycina 4. Powody niewykonywania mikrodermabrazji wodno-tlenowej podane przez kosmetologów, którzy tej metody nie stosowali $(\mathrm{N}=83)$

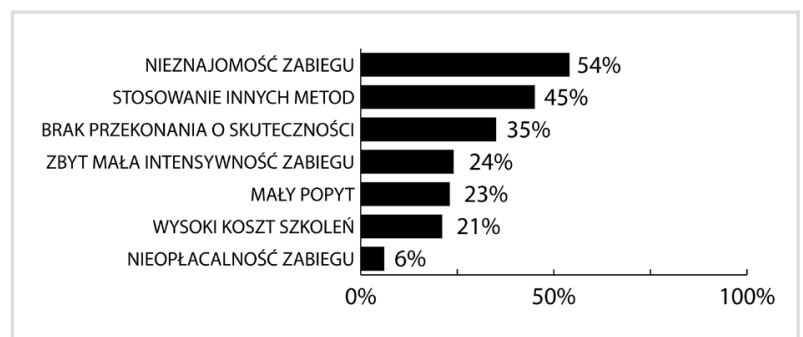

Rycina 5. Motywy wyboru mikrodermabrazji korundowej przez stosujących ją kosmetologów (N=15)

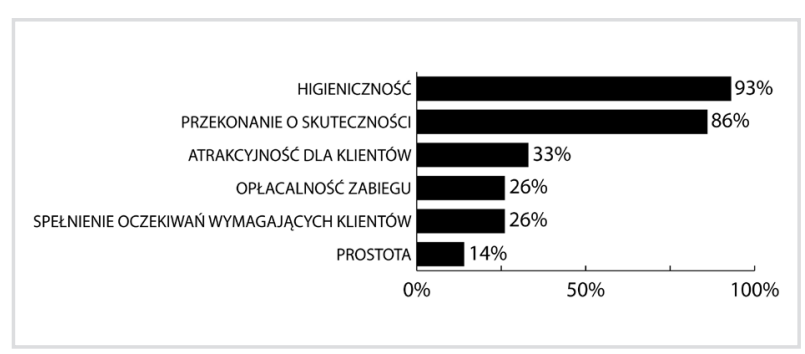

Tabela 5. Skuteczność mikrodermabrazji korundowej w opinii kosmetologów stosujących tę metodę $(\mathrm{N}=15)$

$\begin{array}{llll}\text { Wskazanie } & \begin{array}{l}\text { Zabieg } \\ \text { skutecrny }\end{array} & \begin{array}{l}\text { Zabieg } \\ \text { raczej } \\ \text { skuteczny }\end{array} & \begin{array}{l}\text { Zabieg } \\ \text { nieskuteczny }\end{array} \\ \text { Zmniejszanie szorstkości skóry } & 14(93 \%) & 1(7 \%) & 0 \\ \text { Obkurczanie porów } & 11(74 \%) & 4(26 \%) & 0 \\ \text { Likwidacja rogowacenia okołomieszkowego } & 9(60 \%) & 6(40 \%) & 0 \\ \text { Usuwanie przebarwień } & 7(46 \%) & 6(40 \%) & 2(14 \%) \\ \text { Likwidacja drobnych zmarszczek } & 7(47 \%) & 4(26 \%) & 4(26 \%) \\ \text { Zmniejszanie łojotoku } & 6(40 \%) & 9(60 \%) & 0 \\ \text { Zwiększenie gęstości skóry } & 6(40 \%) & 9(60 \%) & 0\end{array}$


Rycina 6. Powody niewykonywania mikrodermabrazji korundowej podane przez kosmetologów, którzy tej metody nie stosowali $(\mathrm{N}=85)$

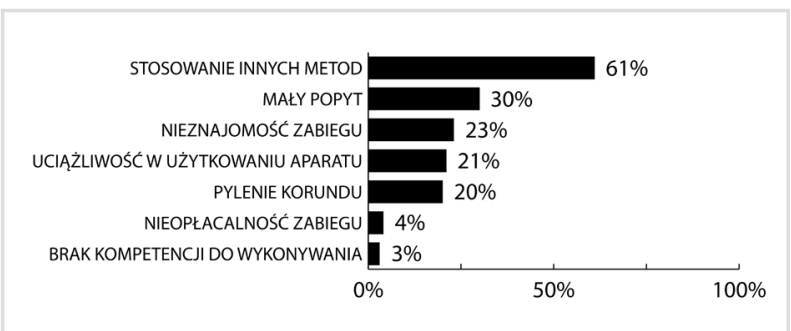

\section{Dyskusja}

Mikrodermabrazja diamentowa jest najczęściej wykonywanym $\mathrm{w}$ gabinetach kosmetycznych zabiegiem złuszczania naskórka. Ankietowani kosmetolodzy wyrażali satysfakcję z efektów zabiegu w usuwaniu przebarwień, obkurczaniu porów skóry, zmniejszania szorstkości i rogowacenia okołomieszkowego, natomiast nie dostrzegali wpływu zabiegów na gęstość skóry. Mikrodermabrazja wodno-tlenowa (oksybrazja) jest najnowszą techniką mikrodermabrazji. Glinka i wsp. [2] po zastosowaniu tej metody obserwowali rozjaśnienie skóry tłustej i mieszanej, redukcję rogowacenia naskórka, stabilizację funkcji gruczołów łojowych, poprawę elastyczności i nawilżenia skóry, a także redukcję blizn i przebarwień. W przypadku osób $\mathrm{z}$ trądzikiem różowatym i teleangiektazjami obserwowali między piątym a dziesiątym zabiegiem zmniejszenie odczynu rumieniowego, po 20-30 aplikacjach dostrzegali też redukcję cellulitu. W naszych badaniach, poza zmniejszeniem szorstkości skóry kosmetolodzy raczej nie dostrzegali tak spektakularnych efektów tego zabiegu. Zabieg mikrodermabrazji korundowej okazał techniką złuszczania naskórka najrzadziej wykonywaną przez kosmetologów. Być może wynika to z faktu, że zabieg ten bardziej niż inne odmiany mikrodermabrazji postrzegany był przez respondentów jako procedura medyczna. Wprawdzie większość kosmetologów uważa, że posiada kompetencje do jego wykonywania, jednak z reguły wybiera inne, mniej inwazyjne techniki. Wśród nielicznych kosmetologów wykonujących tę technikę dominuje zadowolenie $\mathrm{z}$ jej efektów. Ponieważ w dotychczasowych badaniach ocena efektywności poszczególnych odmian mikrodermabrazji opierała się głównie na subiektywnej obserwacji, ocena faktycznej skuteczności tej metody wymaga dalszych badań z zastosowaniem obiektywnych pomiarów aparaturowych lub badań kontrolowanych, w których ocena efektów dokonywana będzie przez badaczy nieświadomych co do rodzaju zastosowanej metody.

\section{Wnioski}

1. Najczęściej wybieranym przez kosmetologów zabiegiem złuszczania naskórka jest mikrodermabrazja diamentowa. Ankietowani rzadziej sięgają po mikrodermabrazję wodno-tlenową, a najrzadziej po mikrodermabrazje korundową.

2. Kosmetolodzy najwyżej oceniają skuteczność mikrodermabrazji korundowej a w dalszej kolejności mikrodermabrazji diamentowej, natomiast mikrodermabrazja wodno-tlenowa uważana jest za najmniej skuteczną.

3. Głównymi motywami wyboru mikrodermabrazji diamentowej przez kosmetologów są duży popyt, prostota wykonywania i opłacalność zabiegu, mikrodermabrazji wodno-tlenowej - higieniczność, bezpieczeństwo i prostota wykonania, zaś mikrodermabrazji korundowej - higieniczność, skuteczność i atrakcyjność.

\section{Piśmiennictwo}

1. Karimipour DJ, Karimipour G, Orringer JS: Microdermabrasion: an evidence-based review. Plast Reconstr Surg 2010; 125(1): 372-7.

2. Glinka M, Dana A: Zastosowanie soli fizjologicznej i tlenu w nowej technologii mikrodermabrazji. Pol J Cosmetol 2008; 11(4): 313-8.

3. Gill HS, Andrews SN, Sakthivel SK, Fedanov A, Williams IR, GarberDA, Priddy FH, YellinS, Feinberg MB, Staprans SI, Prausnitz MR: Selective removal of stratum corneum by microdermabrasion to increase skin permeability. Eur J Pharm Sci 2009; 38(2): 95-103.

4. Shim EK, Barnette D, Hughes K, Greenway HT: Microdermabrasion: a clinical and histopathologic study. Dermatol Surg 2001; 27(6): 524-30.

5. Freedman BM, Rueda-Pedraza E, Waddell SP: The epidermal and dermal changes associated with microdermabrasion. Dermatol Surg 2001; 27(12): 1031-4.

6. Fabbrocini G, Annunziata MC, D'Arco V, De Vita V, Lodi G, Mauriello MC, Pastore F, Monfrecola G: Acne scars: pathogenesis, classification and treatment. Dermatol Res Pract 2010; 2010: 893080 .

7. Alkhawam L, Alam M: Dermabrasion and microdermabrasion. Facial Plast Surg 2009; 25(5): 301-10.

8. Mandy SH: Dermabrasion. Semin Cutan Med Surg 1996; 15(3): 162-9.

9. Tsai RY, Wang CN, Chan HL: Aluminum oxide crystal microdermabrasion. A new technique for treating facial scarring. Dermatol Surg 1995; 21(6): 539-42.

10. Savardekar P: Microdermabrasion. Indian J Dermatol Venereol Leprol 2007; 73(4): 277-9.

11. Freedman BM: Hydradermabrasion: an innovative modality for nonablative facial rejuvenation. J Cosmet Dermatol 2008; 7(4): 275-80.

12. Small R: Aesthetic procedures in office practice. Am Fam Physician 2009; 80(11): 1231-7.

13. Spences JM: Approaches to document the efficacy and safety of microdermabrasion procedure. Dermatol Surg 2006; 32(11): 1353-7. 
14. Bhalla M, Thami GP: Microdermabrasion: Reappraisal and brief review of literature, Dermatol Surg 2006; 32(6): 809-14.

\section{Finansowanie i konflikt interesów}

Przedstawione badania i przygotowanie niniejszej publikacji zostało w całości sfinansowane $\mathrm{z}$ własnych środków autorów. Wszyscy autorzy deklarują niewystępowanie konfliktu interesów w odniesieniu do treści zawartych w niniejszej pracy.

\section{Adres do korespondencji:}

mgr Katarzyna Kordus

Zakład Dermatologii Doświadczalnej i Kosmetologii

UJ CM, ul. Medyczna 9, 30-688 Kraków

Tel.: 1262058 30, Fax: 126205645

E-mail: katarzyna.kordus@uj.edu.pl

Data złożenia: 12.08.2011

Data akceptacji: 29.08.2011

Data aktualizacji: 30.11.2011 